\title{
Recurrent Urethral Urothelial Carcinoma
}

National Cancer Institute

\section{Source}

National Cancer Institute. Recurrent Urethral Urothelial Carcinoma. NCI Thesaurus. Code C131218.

The reemergence of transitional cell carcinoma in the urethra after a period of remission. 